\title{
Stabilisation of surface and photoluminescent properties of porous silicon
}

\author{
Olenych I.B. \\ Ivan Franko Lviv National University, 50 Dragomanov St., 79005 Lviv, Ukraine, \\ e-mail: iolenych@gmail.com
}

Received: 11.02 .2011

\begin{abstract}
Using photoluminescence and infrared spectroscopy techniques, we have investigated the influence of surface molecular composition of porous silicon (PS) on the character of its photoluminescence spectra. The main absorption bands of PS in the infrared spectral range are found to be caused by hydride passivation of silicon nanocrystals, adsorption of water molecules and hydroxyl groups during the process of PS formation, as well as by the adsorption of oxygen and carbon due to oxidation of PS. Additional absorption bands found for PS-polyaniline composites are caused by oscillations of molecules that make up the structural polymer chains. The physical and chemical conditions needed for improving photoluminescence stability by means of passivating the PS surface by oxygen and polymer films are substantiated.
\end{abstract}

Keywords: porous silicon, polyaniline, photoluminescence, infrared transmission spectra, surface passivation.

PACS: $78.55 . \mathrm{Mb}, 81.05 . \mathrm{Rm}$

UDC: $535.37,538.958$

\section{Introduction}

Layers of nanostructured porous silicon (PS) have a wide range of unique electronic and optical properties caused by quantum size effects [1]. Discovery by Canham, in 1990, of an intense visible photoluminescence (PL) of the PS at room temperature (see, e.g., [1]) has opened novel prospects for using silicon in active elements for optoelectronics (light emitting diodes, phosphors, optical transmission media, etc.) and brought forth fundamentally new ideas of integration based on silicon technology. An essential point limiting applications of PS in optoelectronics is its high surface sensitivity. On the one hand, this is a negative factor leading to instability of the PS in air. On the other hand, this represents also some positive factor, since one can use this material for fabrication of sensors.

A significant impact on PL of the PS comes from its developed surface (the area density of $800 \div 1000 \mathrm{~m}^{2} / \mathrm{sm}^{3}$ ) which, immediately after anodisation, is extremely sensitive to adsorption of various chemical compounds. As a result of uncontrolled changes in the chemical composition of the porous layer, unpredictable changes in the optical properties of the material take place. They manifest themselves, e.g., in changes in the PL spectra of PS under conditions of air atmosphere. Relaxation processes in the luminescence of PS have been observed in many works, alongside with degradation of light emission under 
influence of chemical factors and long-term storage of the PS [1-5]. In the process of aging, the PL spectra are being transformed: the radiation intensity is reducing and the spectra themselves are shifting towards the short-wavelength range. These processes are associated with adsorption of hydrogen or $\mathrm{Si}-\mathrm{H}_{\mathrm{x}}$ complexes $(x=1,2,3)$ which determine concentration of nonradiative recombination centres (broken bonds of silicon) [6,7], or with oxidation of silicon pore walls. The most important results on stabilisation of the luminescent properties of PS have been obtained using inactivation of the broken bonds of silicon, fast oxidation, and modification of electrolyte which forms the PS [8-10]. The common feature of these methods for stabilising the surface of PS is substitution of unstable complexes $\mathrm{Si}-\mathrm{H}_{\mathrm{x}} \quad(x=1,2,3)$ with more stable $\mathrm{Si}-\mathrm{O}$ ones. Moreover, comprehensive studies of molecular composition of the surface and luminescent properties of the PS should develop into establishing role of the surface in photoluminescence processes of the PS.

\section{Experiment}

The PS was formed by electrochemical anodisation of silicon in a water-ethanol solution of hydrofluoric acid. We used a experimental setup in which a silicon sample (anode) and a platinum cathode were placed into a fluoroplastic cell. The anodic current density was $25 \div 35 \mathrm{~mA} / \mathrm{cm}^{2}$ for different samples, while the duration of anodisation process was 20 min. During the anodic etching of silicon in hydrofluoric acid, formation of narrow pores takes place, which are directed inside a crystal. The pores gradually expand until the walls are partially etched. As a result, residuals of walls, or so-called quantum wires, remain. In order to study the topology of PS, we used an atomic-force microscope SZM SOLVER PRO. After anodising the PS surface had the form of vertical nanowires (cylindrical nanocrystals), with the dimensions from several nanometres to tens of nanometres in the cross section, although there happened somewhat bigger structures $(100 \div 400 \mathrm{~nm}$ in the base - see Fig. 1).

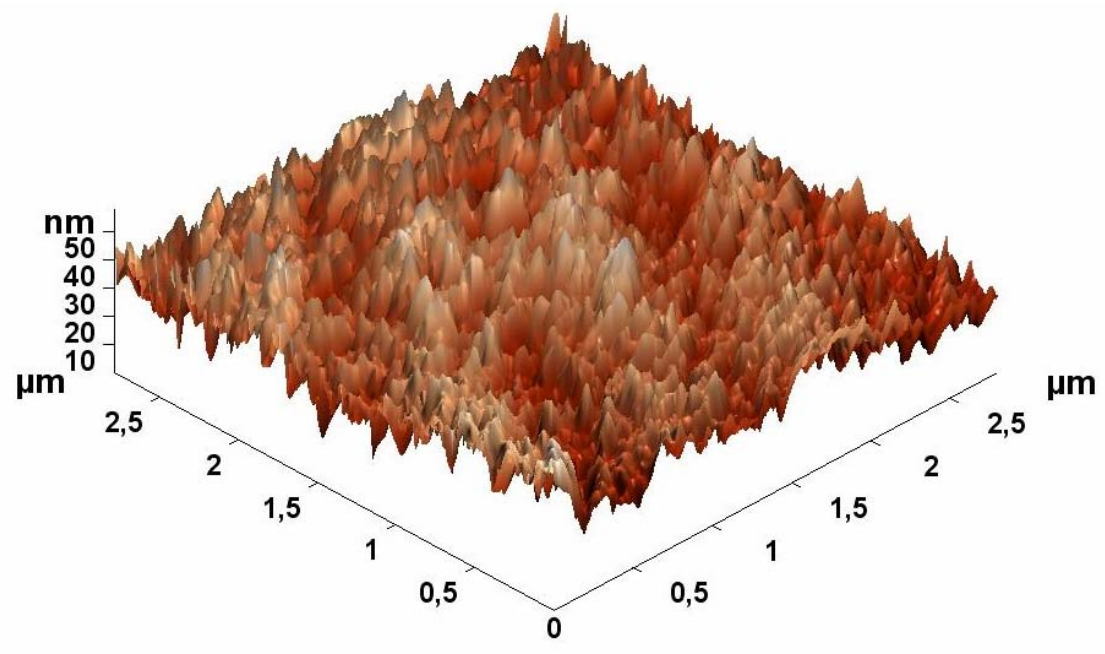

Fig. 1. AFM images of PS surface. 
Small size of silicon crystals and large total area of their surface give rise to great sensitivity of PS layer properties to the environment. Silicon oxide passivates well the surface of PS nanocrystals, resulting in reduced nonradiative recombination. Thermal oxidation of the PS was conducted in a stream of water vapour at the temperature of 1173 $\mathrm{K}$ for $30 \mathrm{~min}$. However, thermal annealing had led to complete quenching of the PL.

Taking into account the fact that thermal annealing of the PS at temperatures higher than $600 \mathrm{~K}$ leads to PL quenching, we have chosen electrochemical anodic oxidation of porous layer in a solution of $\mathrm{H}_{2} \mathrm{O}_{2}$ in galvanostatic mode as an optimum method for oxygen passivation (the current density of $10 \mathrm{~mA} / \mathrm{cm}^{2}$ and the duration of $15 \mathrm{~min}$ ). High efficiency of using $\mathrm{H}_{2} \mathrm{O}_{2}$ for oxidation of porous layers in the water-ethanol solution of $\mathrm{HF}$ for the formation of PS has been noticed for the first time in the work [11].

Another method for stabilising molecular composition of the PS surface has been passivation of the surface by a polymer transparent to both radiation and excitation quanta. A protective film of polyaniline (PAN) was deposited on the surface of porous layer by electrochemical polymerisation (see [12]), in which the polymer was formed directly on the electrode surface (i.e., on the PS) from a monomer solution ( $0.1 \mathrm{M}$ aniline solution in $0.5 \mathrm{M} \mathrm{H}_{2} \mathrm{SO}_{4}$ ). For this aim we used a special electrochemical cell in which the working electrode served like a PS and auxiliary electrode was a platinum plate. The process of electrodeposition of the polymer on the PS surface was carried out in a cyclic potential scanning run (the rate of $80 \mathrm{mV} / \mathrm{s}$ and the range of $-0.4 \div 1.5 \mathrm{~V}$ ). There were 15 cycles of scanning.

Molecular composition of the PS surface and the PS-PAN structures were studied using an infrared (IR) spectroscopy. The corresponding IR spectra were measured with a spectrometer AVATAR in the $400 \div 4000 \mathrm{~cm}^{-1}$ range. The absorption bands were identified based on the comparison with the known literature data [4, 5, 13-15]. Studies of the PL of PS were performed in the spectral range of $500 \div 850 \mathrm{~nm}$, using a standard optical equipment. The luminescence was excited with a pulse nitrogen laser LGI-21 (the wavelength $337 \mathrm{~nm}$ and the pulse duration $8 \mathrm{~ns}$ ). The PL spectra were corrected with accounting for spectral sensitivity of our setup.

\section{Results and discussion}

The analysis of the IR spectra of PS has shown that most of the absorption bands are related to molecular complexes containing hydrogen and oxygen (see Fig. 2). The most marked absorption bands are those corresponding to $620 \mathrm{~cm}^{-1}$ ( $\mathrm{Si}-\mathrm{H}_{2}$ deformation modes) and $1075 \mathrm{~cm}^{-1}$ (valence oscillations of $\mathrm{Si}-\mathrm{O}-\mathrm{Si}$ ). The oscillations of $\mathrm{Si}-\mathrm{O}-\mathrm{C}$ are responsible for the absorption band located at the frequency of $1240 \mathrm{~cm}^{-1}$. In addition, the IR spectra of the PS include the bands in the regions of $1450 \div 1760$ and $2350 \div 2400 \mathrm{~cm}^{-1}$. They are related to deformation modes of $\mathrm{Si}-\mathrm{CH}_{3}$ and oscillations of $\mathrm{O}_{3}-\mathrm{Si}-\mathrm{H}$, respectively.

The presence of a large number of carbon compounds may be explained by both a noticeable content of ethanol in the electrolyte in the case of anodisation and adsorption 
of carbon due to its stay in the air. The broad absorption band in the region of $2900 \div 3800 \mathrm{~cm}^{-1}$ is attributed to oscillations of $\mathrm{O}-\mathrm{H}$ bonds in the water molecules, which are adsorbed on the PS surface. In the same spectral region we have observed the absorption bands related to hydroxyl groups of $\mathrm{Si}-\mathrm{OH}$ and molecular complexes of $\mathrm{Si}-\mathrm{H}_{2}$, $\mathrm{Si}-\mathrm{H}_{3}$ and $\mathrm{C}-\mathrm{H}$.

The anode oxidation leads to increasing intensity of the $1100 \mathrm{~cm}^{-1}$ band in the IR spectra, being an indication of increased part of the oxide in our PS samples. Moreover, some redistribution of the intensities of shoulders of certain bands and a shift of their peaks take place, thus proving transformation of composition of the porous surface layer. The absorption inside the bands characteristic for the $\mathrm{Si}-\mathrm{H}_{\mathrm{x}}$ complexes is much weaker in comparison with that observed for the initial PS samples. The bands located in the region of $2900 \div 3800 \mathrm{~cm}^{-1}$ and related to the $\mathrm{O}-\mathrm{H}$ bonds of adsorbed water molecules have not been observed in the IR spectra of thermally oxidised PS. Besides, the absorption band attributed to deformation oscillations of the $\mathrm{Si}-\mathrm{O}$ group has been found at the frequency of $460 \mathrm{~cm}^{-1}$.

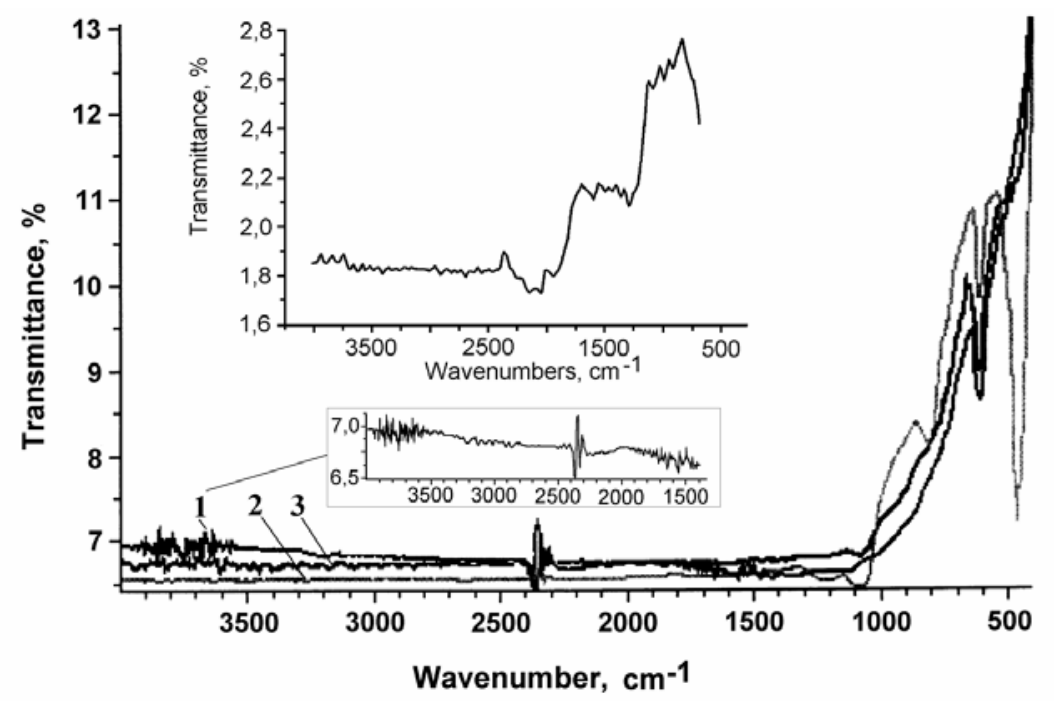

Fig. 2. IR absorption spectrum of PS (curve 1) and the same spectra of thermally oxidised (curve 2) and anode-oxidised (curve 3) layers of the PS. Insert shows IR absorption spectrum of the PAN-PS-Si structure.

Deposition of polyaniline films on the surface of PS films causes reduction of light transmission in the IR range, which may be explained by additional light absorption by the polymer. The IR absorption spectrum of the PAN-PS-Si structure has additional absorption bands which are not observed in the IR spectrum of PS. In the $1350 \div 1620 \mathrm{~cm}^{-1}$ region, we have identified a set of absorption bands associated with polymer coating of the porous layer. Here the absorption line with the peak at $1353 \mathrm{~cm}^{-1}$ is associated with molecular complexes containing nitrogen, while the lines at $1428 \mathrm{~cm}^{-1}$ and $1599 \mathrm{~cm}^{-1}$ are due to oscillations of benzene ring in the PAN structure. In the region of wavelength numbers of $2800 \div 3000 \mathrm{~cm}^{-1}$ we have detected a number of bands that are identified as 
absorption at the asymmetric valence bonds of $\mathrm{C}-\mathrm{H}_{\mathrm{x}}$. This may be explained by passivation of the PS surface by polyaniline $\mathrm{C}-\mathrm{H}_{3}\left(2814 \mathrm{~cm}^{-1}\right)$ and $\mathrm{C}-\mathrm{H}_{2}\left(2919 \mathrm{~cm}^{-1}\right)$.

Investigations of the PL properties of PS samples which have been kept in the air for a long time (e.g., for several months) show a slight decrease of the PL intensity and a shift of the spectrum towards the short-wavelength region (by $15 \div 20 \mathrm{~nm}-$ see Fig. 3), with the total spectrum width narrowing at the expense of decreasing intensity of the long-wavelength wings. The shift of the spectral maximum in the higher-energy region may be related to oxidation of the PS surface which imposes reduced size of the nanocrystals (i.e., the appearance of quantum dots and wires). During exposition at the atmospheric conditions, the atomic composition of the sample surface has become stabilised and a part of hydride groups have been substituted by oxygen [4].
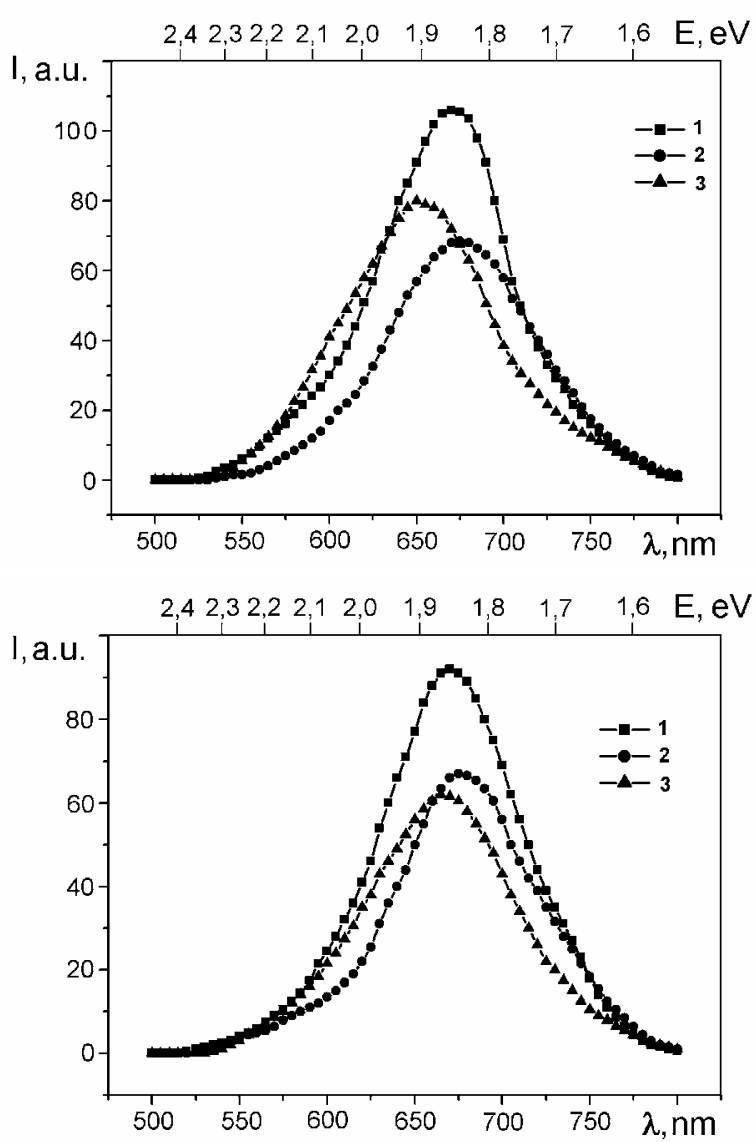

Fig. 3. PL spectra of initial PS sample (curve 1) and those aged for 100 days in vacuum (curve 2) and air (curve 3).

Fig. 4. PL spectra of initial PS sample (curve 1) and sample anodeoxidised in $\mathrm{H}_{2} \mathrm{O}_{2}$ (curve 2). Curve 3 shows transformation of curve 2 occurring after 100 days in the air.

Having analysed the changes observed in the PL spectra of the layers under exposition of PS in the air for a long time, we conclude that there is a correlation between the atomic composition of the silicon nanocrystal surface and the PL properties of the latter. Similar processes (oxidation and desorption of substances from the surface of porous layer) occur due to anodic oxidation of PS in $\mathrm{H}_{2} \mathrm{O}_{2}$ solution, though the rate of these processes is significantly higher. Oxygen passivation of the PS surface during the anodic oxi- 
dation results in more stable luminescent properties of the porous layers, when compared with the case of PS kept in vacuum or air (see Fig. 4).

Passivation of the PS surface has been further improved owing to formation of $\mathrm{Si}-\mathrm{O}-\mathrm{Si}$ bonds. This is a probable cause for stabilising the visible PL of the porous layers. Similar to the case of bulk silicon, the nonradiative recombination in the PS takes place mainly through defect centres on the surface. Here the silicon atoms with broken bonds can play a part of such defects (see [7]). A decrease observed in the PL intensity is related to changing nature of passivation of the surface. The spectral position of the PL maximum for the anode-oxidised PS layer changes with time to a lesser extent in comparison with freshly prepared samples. The influence of the adsorption of molecules on the PL spectra of PS decreases with increasing thickness of the oxide layer, which separates silicon nanocrystals and adsorbed elements. However, the anodic oxidations of the walls between the pores have not allowed reaching the required level of surface passivation and its time stability.

After deposition of polyaniline film on the PS samples obtained under different technological conditions (e.g., using bulk Si doped by both phosphorus and stibium), we have observed a weak increase in the integral PL intensity in the $550 \div 800 \mathrm{~nm}$ region, when compared with the initial samples (see Fig. 5).

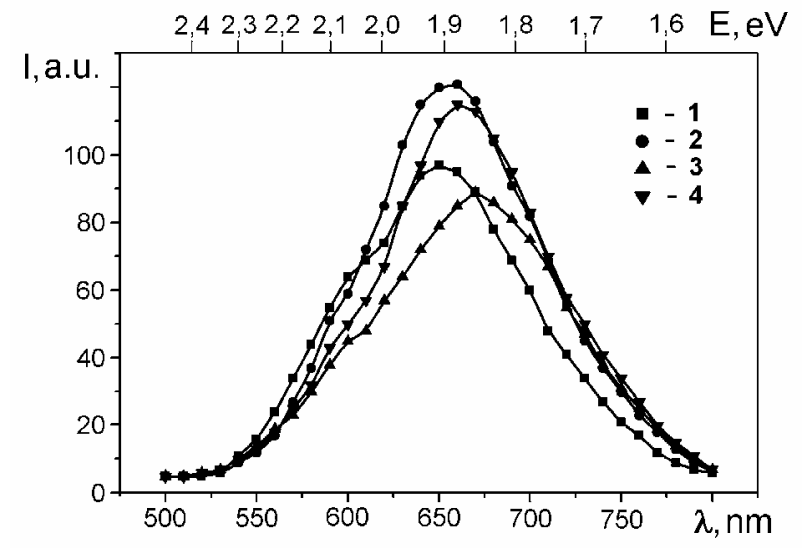

Fig. 5. $P L$ spectra detected for initial PS (curves 1 and 3 ) and PAN-PS-Si structure (curves 2 and 4).

A slight increase in the PL intensity of PS is explained by better surface passivation of the porous layer using the polymer coating. In addition, the polymer coating does not change the luminescent properties of the PS. The efficiency of using the polymer films as stabilising coating is also supported by invariance of the PL spectra for the PS kept both in a special atmosphere and in the air for a long (more than 3 months) time.

\section{Conclusions}

The analyses of our combined studies for the molecular composition of the porous layer surface and its PL properties testify that the peculiarities of relaxation-degradation processes in the PS are related to the changes in chemical composition of the surface. The IR spectroscopy has detected that the PS contains hydrogen in the form of $\mathrm{Si}-\mathrm{H}_{\mathrm{x}}$ groups, 
which are substituted, due to oxidation, by the oxygen-containing groups, $\mathrm{Si}-\mathrm{O}-\mathrm{Si}$ and $\mathrm{O}_{3}-\mathrm{Si}-\mathrm{H}$. Furthermore, a presence of complexes containing carbon has also been detected. The additional absorption bands observed in the PAN-PS structures under test confirm surface passivation of the polymer films. Our results demonstrate a clear possibility for surface passivation of the luminescent PS nanocrystals, using oxygen and polymer films. This can be employed for improving stability and reducing degradation of light emitting. Thin polyaniline film coating is transparent for both the exciting radiation and the one generated in the PS. Thus, this coating can be used while reducing degradation processes and protecting the PS from mechanical and atmospheric influences.

\section{References}

1. Properties of porous silicon. Ed. by Canham L. London: INSPEC (1997).

2. Venger E F, Gorbach T Ya, Kirillova S I, Primachenko V E and Chernobai V A, 2002. Changes in properties of a <porous silicon>/silicon system during gradual etching off of the porous silicon layer. Semiconductors. 36: 330-335.

3. Agekyan V F, Aprelev A M, Laiho R and Stepanov Yu A, 2000. Effect of contact with air on the photoluminescence spectrum of porous silicon. Phys. Sol. St. 42: 1431-1434.

4. Fukuda Y, Furuya K, Ishikawa N and Saito T, 1997. Aging behavior of photoluminescence in porous silicon. J. Appl. Phys. 82: 5718-5721.

5. Maruyama T and Ohtani S, 1994. Photoluminescence of porous silicon exposed to ambient air. Appl. Phys. Lett. 65: 1346-1348.

6. Hadj Zoubir N, Vergnat M, Delatour T, Burneau A and de Donato Ph, 1994. Interpretation of the luminescence quenching in chemically etched porous silicon by the desorption of $\mathrm{SiH}_{3}$ species. Appl. Phys. Lett. 65: 82-84.

7. Jung K H, Shih S and Kwong D L, 1993. Developments in luminescent porous Si. J. Electrochem. Soc. 140: 3046-3064.

8. Qin G G, Song H Z, Zhang B R, Lin J, Duan J Q and Yao G Q, 1996. Experimental evidence for luminescence from silicon oxide layers in oxidized porous silicon. Phys. Rev. B. 54: 2548-2555.

9. Kostishko B M, Puzov I P and Nagornov Yu S, 2000. Stabilization of luminous properties of porous silicon by vacuum annealing at high temperatures. Tech. Phys. Lett. 26: 26-28.

10. Gavrilov S A, Belogorokhov A I and Belogorokhova L I, 2002. A mechanism of oxygen-induced passivation of porous silicon in the $\mathrm{HF}: \mathrm{HCl}: \mathrm{C}_{2} \mathrm{H}_{5} \mathrm{OH}$ solutions. Semiconductors. 36: 98-101.

11. Yamani Z, Thompson W H, Abu Hassan L and Nayfeh M H, 1997. Ideal anodization of silicon. Appl. Phys. Lett. 70: 3404-3406.

12. Aksimentyeva O. Electrochemical methods of synthesis and conductivity of conjugated polymers. Lviv: Svit (1998). 
13. Borghesi A, Sassella A, Pivac B and Pavesi L, 1993. Characterization of porous silicon inhomogeneities by high spatial resolution infrared spectroscopy. Sol. St. Commun. 87: $1-4$.

14. Niwano M, 1999. In-situ IR observation of etching and oxidation processes of Si surfaces. Surf. Sci. 427-428: 199-207.

15. Tarutino L. and Pozdnyakova F. Spectral analysis of polymers. Leningrad: Chemistry (1986).

Olenych I.B., 2011. Stabilisation of surface and photoluminescent properties of porous silicon. Ukr.J.Phys.Opt. 12: 54-61.

Анотація. Методами фотолюмінесцениії та інфрачервоної спектроскопії досліджено вплив поверхневого молекулярного складу поруватого кремнію (ПК) на характер його спектрів фотолюмінесцениії. Встановлено, що основні смуги поглинання в інфрачервоному спектрі ПК зумовлені гідридною пасивацією поверхні кремнієвих нанокристалів, адсорбиією молекул води і гідроксильних груп у прочесі формування ПК, а також адсорбиією кисню та вуглеию внаслідок окислення ПК. Додаткові смуги поглинання, що з'являються в композитах ПК-поліанілін, зумовлені коливаннями молекул, що складають структурну ланку полімеру. Обтрунтовано фізико-хімічні умови покращення стабільності фотолюмінесценції ПК шляхом пасивачії його поверхні киснем і полімерними плівками. 